\title{
The effect of drier outflow temperature on rumen protein degradability and intestinal digestibility of rumen- undegraded protein of dehydrated grass and lucerne
}

\author{
ZM Kowalski 1, PMP Pisulewski 2, JL Peyraud 3, J Kaminski 1 \\ 'Agricultural University of Cracow, Department of Animal Nutrition, 30-059 Krakow, Al.Mickiewicza 24/28; \\ 2Institute of Animal Production, 32-083 Balice, Poland; 3INRA Station de Recherches \\ sur la Vache Laitière, 35590 St-Gilles, France
}

Dehydrated herbage may be a valuable source of protein in dairy cow diets (Peyraud et al, 1994). High temperature required during dehydratation may positively decrease protein degradability in the rumen (Kowalski and Kaminski, 1993) ; on the other hand it can also negatively decrease digestibility of rumenundegraded protein in the intestine. The aim of this study was to determine the effect of drier outflow temperature $\left(123,133,143\right.$ and $\left.153^{\circ} \mathrm{C}\right)$ on dehydrated grass and lucerne protein degradability in the rumen as well as on rumen-undegraded protein digestibility in the intestine.

The experiment was conducted on three dry cows, equipped with ruminal and duodenal cannulae, and fed with standard diets. Rumen degradability (in sacco) was determined according to Michalet-Doreau et al (1987). Total tract protein disappearance (TTPD) was determined by incubation of nylon bags in the rumen for $16 \mathrm{~h}$ then in a pepsin bath $(2.5 \mathrm{~h}$, $38.5^{\circ} \mathrm{C}$ ) and then in the duodenum (mobile nylon bags), according to Peyraud et al (1988). The intestinal digestibility of rumenundegraded protein (IUPD) was estimated from crude protein (CP) content, its effective

Temperature ${ }^{\circ} \mathrm{C}$
Dehydrated grasses
Crude protein (g/kg DM)
ADIN \% N
DG
TTPD (\%)
IUPD (\%)
Dehydrated lucerne
Crude protein (g/kg DM)
ADIN \% N
DG
TTPD (\%)
IUPD (\%)

123
172.5
13.0
52.1
$91.3^{A}$
81.8
185.6
14.5
63.4
$92.0^{A a}$
78.0

degradability in the rumen calculated at outflow rate $k=0.06(D G)$ and $T T P D$, using the following equation : IUPD $=100 \times(C P \times(100-$ DG) - CP $\times(100-$ TTPD $)) /(C P \times(100-D G))$.

An increase in drier outlow temperature decreased crude protein content slightly and increased ADIN \% $\mathrm{N}$ in dehydrated grass. These tendencies were not seen for dehydrated lucerne.

Temperature significantly reduced dehydrated grass protein degradability in the rumen. The decrease in effective protein degradability of dehydrated grass dried at $153^{\circ} \mathrm{C}$ resulted from the decrease of the degradation rate (c) of unsoluble but degradable protein fraction (b). For dehydrated lucerne these effects were not observed.

The increase of temperature significantly reduced TTPD. In case of dehydrated grass it was particularly seen at $153^{\circ} \mathrm{C}$. Average estimated intestinal digestibilities of rumenundegraded dietary protein were 79.3 and $76.5 \%$, for dehydrated grass and lucerne respectively. Temperature $153^{\circ} \mathrm{C}$ significantly reduced IUPD of dehydrated grass.

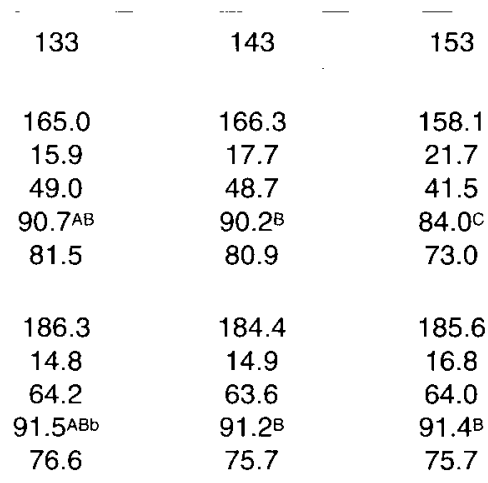

$D G$ - effective rumen protein degradability at $\mathrm{k}=0.06$; TTPD - total tract protein disappearance from mobile nylon bag ; IUPD - calculated intestinal rumen-undegraded protein digestibility 